\title{
The Accuracy of Memorial Sloan-Kettering Cancer Center Nomogram in Anatolian Breast Cancer Patients
}

\section{Memorial Sloan-Kettering Cancer Center Nomogramının Anadolu'da Yaşayan Meme Kanseri Hastalarındaki Doğruluğu}

\author{
Osman Erdoğan ${ }^{1}$, Ulvi Murat Yüksel ${ }^{1}$, Uğur Berberoğglu ${ }^{1}$, Kaptan Gülben $^{1}$, Bülent Aksel ${ }^{1}$, Osman Uyar $^{1}$, \\ Müjdat Turan ${ }^{1}$
}

${ }^{1}$ Dr. Abdurrahman Yurtaslan Ankara Onkoloji Eğitim Ve Araştırma Hastanesi, Ankara, Türkiye

Dergiye Ulaşma Tarihi:23/02/2016 Dergiye Kabul Tarihi: 08/05/2016 Doi: 10.5505/aot.2016.04127

\section{ÖZET}

Amaç: Bir çok meme kanseri hastasında sentinel lenf nodundan başka metastatik lenf nodu olmadı̆̆ halde gereksiz yere aksiller diseksiyon uygulanmaktadır. Bu çalışmanın amacı Memorial Sloan-Kettering Cancer Center (MSKCC) nomogramının Anadolu'da yaşayan meme kanseri hastalarındaki doğruluğunu araştırmaktır.

Gereç ve yöntem: Sentinel lenf nodu (SLN) biyopsisi pozitif olduğu için aksiller lenf nodu diseksiyonu yapılan 120 meme kanserli hastanın hasta ve tümör özellikleri irdelendi. Bu hastaların her birisinin non-SLN tutulum riski MSKCC nomogramı kullanılarak hesaplandı.

Bulgular: Negatif SLN sayıs1, pozitif SLN sayısı, SLN ekstrakapsüler yayılımı, pozitif SLN sayısının toplam SLN sayısına oranı (pozitif SLN oranı), lenfovasküler invazyon varlığı, tumor çapı, human epidermal growth factor receptor-2 durumu tek değişkenli analizde non-SLN metastazı ile istatistiksel olarak ilişkili bulunan faktörlerdi. Çok değişkenli analizde ise tümör çapı $\geq 5 \mathrm{~cm}(\mathrm{p}<0.036)$ ve pozitif SLN oranı $(\mathrm{p}<0.005)$ non-SLN metastazı ile ilişkili bulunan parametrelerdi. Nomogramın sonucuna göre ROC eğrisi çizildi ve eğri altı alan $0,779$ ( $\mathrm{p}<0.001)$ olarak bulundu.

Sonuç: SLN pozitif meme kanserli hastalarda non-SLN metastaz riskini belirlemede MSKCC nomogramı bizim hasta populasyonumuz için iyi bir ayıraç olmuştur.

Anahtar kelimeler: Meme kanseri, nomogramlar, lenf nod diseksiyonu

\section{ABSTRACT}

Background and Aim: Many breast cancer patients undergo to unnecessary axillary dissection as additional nodal metastasis is not detected other than sentinel lymph node in most of the patients. This study is conducted to establish the accuracy of Memorial Sloan-Kettering Cancer Center (MSKCC) nomogram in Anatolian patients.

Materials and Methods: One hundred and twenty sentinel lymph node (SLN) biopsy positive breast cancer patients who received completion axillary lymph node dissection were reviewed according to patient and tumour characteristics. The likelihood of having positive non-SLN metastasis based on the factors and the performance of the diagnostic value of MSKCC nomogram were evaluated.

Results: The number of negative SLNs, the number of positive SLNs, SLN extracapsular extention, proportion of positive SLNs to total SLNs (positive SLN ratio), lymphovascular invasion, tumor size, human epidermal growth factor receptor-2 status were found statistically significant on non-SLN metastasis in univariate analysis. Tumor size $\geq 5 \mathrm{~cm}(\mathrm{p}<0.036)$ and positive SLN ratio $(\mathrm{p}<0.005)$ were found to be correlated with non-SLN metastasis in multivariate analysis. Receiver operating characteristic (ROC) curve was formed according to the nomogram and areas under curve (AUC) was found as $0,779(\mathrm{p}<0.001)$.

Conclusions: The MSKCC nomogram was good discriminator of non-SLN metastasis in SLN positive breast cancer patients for our patient population.

Key Words: breast cancer, nomograms, lymph node dissection 


\section{Introduction:}

Breast cancer is the most common cancer type among women in the world and 1.67 million new cases diagnosed each year [1]. The identification of clinical, pathological and biological factors such as tumour size, axillary lymph node status, hormonal receptor and human epidermal growth factor receptor-2 (HER-2) status have a role in risk stratification and affect treatment modality in breast cancer [2]. Axillary lymph node metastasis is the most important prognostic factor in breast cancer and therefore to determine the axillary lymph node status is the principle together with the resection of primary tumour [3]. If there is sentinel lymph node (SLN) metastasis, axillary lymph node dissection (ALND) is still the standard procedure for breast cancer patients; however, additional nodal metastasis is detected in the rest of axilla in only about $40 \%-70 \%$ of these patients [4]. Therefore, many patients undergo to unnecessary axillary dissection. The importance of sentinel lymph node biopsy (SLNB) is because of the complications like seroma, lymphedema, nerve injury and frozen shoulder in the patients those who receive ALND. To identify the possible risk of non-SLN metastasis, Memorial SloanKettering Cancer Center (MSKCC) developed a nomogram in 2003.

We conducted this study to establish the accuracy of the nomogram in Anatolian patients those who were referred to a single tertiary centre.

\section{Materials and Methods:}

Totally 120 breast cancer patients who lived in Anatolia and ALND applied because of positive SLNB between December 2011 and May 2013 were included in this study. The study protocol was approved by the Ethics Committee of Ankara Oncology Training and Research Hospital. Patients who had clinically axillary lymph node positivity, received neoadjuvant therapy or received axillary surgical manuplation before and those who failed in successfully locating SLN were excluded. Both lymphosintigraphy and metilen blue technique was used to locate SLN. SLNB was applied either through the same insicion with mastectomy or through another minimal incision. Gama probe was used for the identification of sentinel lymph node/nodes and frozen section was carried out on the biopsy material. Simultaneous ALND applied in all the patients those whom SLNB result reported as micrometastasis or macrometastasis. SLNB material was also analyzed by immunohistochemistry postoperatively. Patient's age, tumour size and histology, nuclear grade, presence of lymphovascular invasion (LVI), SLN extracapsular extention and multifocality of the tumor, the number of removed SLNs, the number of positive and negative SLNs, the method of detection of SLNs [frozensection (FS), routine haematoxylin \& eosin, serial section haematoxylin \& eosin and immunohistochemistry (IHC)], estrogen receptor, progesterone receptor, HER2 receptor and KI67 status were recorded. The likelihood of non-SLN metastasis based on the factors were evaluated by using chi square test, student t-test and Mann Whitney $U$ test. Logistic regression analysis was used on the multivariate method.

The areas under curve (AUC), the receiver operating characteristic curve (ROC) were used to describe the performance of the diagnostic value of MSKCC. www.mskcc.org/applications/nomograms/brea st/BreastAdditionalNonSLNMetastasesPage.as $\mathrm{px}$ is the web site address for MSKCC Nomogram. SPSS 15 program was used for evaluating the risk factors in axillary metastasis.

\section{Results:}

There were total 120 patients all women with mean age $49.48( \pm 11.21)$. There were 53 patients $(44 \%)$ in Group- 1 with positive nonSLN and 67 patients $(55.8 \%)$ with negative non-SLN in Group-2. Groups were similar according to age, tumour type, multifocality, nuclear grade, ER and PR status. Patients and tumour characteristics are shown in table-1.

Frozen section was the method used for the pathological verification of non-SLN in 53 patients (100\%) in Group-1 and 63 patients $(94 \%)$ in Group-2. IHC was used for pathological verification of non-SLN in 4 patients (6\%) in Group 2. The method used for the pathological verification of non-SLN did not differ significantly between the groups 
Table 1: Patient and tumour characteristics

\begin{tabular}{|c|c|c|c|c|}
\hline & & Group $1(\mathrm{n} \%)$ & Group $2(\mathrm{n} \%)$ & $\mathrm{p}$ \\
\hline \multirow{2}{*}{ Age } & $0-50$ & $32(\% 60.4)$ & $39(\% 58.2)$ & \multirow{2}{*}{0.479} \\
\hline & $\geq 51$ & $21(\% 39.6)$ & $28(\% 41.8)$ & \\
\hline \multirow{2}{*}{ Tumour Size } & T1-T2 & $44(\% 83)$ & $65(\% 97)$ & \multirow{2}{*}{0.010} \\
\hline & T3 & $9(\% 17)$ & $2(\% 3)$ & \\
\hline \multirow{2}{*}{ Tumour Type } & IDK & $50(\% 94.3)$ & $60(\% 89.6)$ & \multirow{2}{*}{0.275} \\
\hline & ILK & $3(\% 5.7)$ & $7(\% 10.4)$ & \\
\hline \multirow{2}{*}{ Nuclear Grade } & $1-2$ & $23(\% 43.4)$ & $35(\% 52.2)$ & \multirow{2}{*}{0.218} \\
\hline & 3 & $30(\% 56.6)$ & $32(\% 47.8)$ & \\
\hline \multirow{2}{*}{ LVI } & + & $25(\% 47.2)$ & $11(\% 16.4)$ & \multirow{2}{*}{0.001} \\
\hline & - & $28(\% 52.8)$ & $25(\% 83.6)$ & \\
\hline \multirow{2}{*}{ HER-2 } & + & $27(\% 50.9)$ & $12(\% 17.9)$ & \multirow{2}{*}{0.001} \\
\hline & - & $26(\% 49.1)$ & $55(\% 82.1)$ & \\
\hline \multirow{2}{*}{$\begin{array}{c}\text { Metastatic SLN } \\
\text { Ratio }\end{array}$} & Ratio $=1$ & $35(\% 66)$ & $20(\% 29,9)$ & \multirow{2}{*}{0.001} \\
\hline & Ratio $\leq 1$ & $18(\% 34)$ & $47(\% 29.9)$ & \\
\hline \multirow{2}{*}{$\begin{array}{c}\text { SLN } \\
\text { Extracapsuler } \\
\text { Extention }\end{array}$} & + & $30(\% 56.6)$ & $20(\% 29.9)$ & \multirow{2}{*}{0.003} \\
\hline & - & $23(\% 43.4)$ & $47(\% 79.1)$ & \\
\hline
\end{tabular}

LVI: Lenfovascular Invasion, HER-2 : Human Epidermal Growth Factor Receptor-2 
Table 2: The significant factors identified in univariate analysis

\begin{tabular}{|l|l|}
\hline \multicolumn{1}{|c|}{ Variables } & P Value \\
\hline Tumour Size & 0,002 \\
\hline Tumour Size $\geq 5 \mathrm{~cm}$ & 0,01 \\
\hline LVI & 0,001 \\
\hline Metastatic SLN Ratio & 0,001 \\
\hline $\begin{array}{l}\text { The number of positive } \\
\text { SLN }\end{array}$ & 0,001 \\
\hline $\begin{array}{l}\text { The number of negative } \\
\text { SLN }\end{array}$ & 0,001 \\
\hline HER-2 & 0,001 \\
\hline Extracapsular Extension & 0,003 \\
\hline LVI LLa
\end{tabular}

LVI: Lenfovascular Invasion,

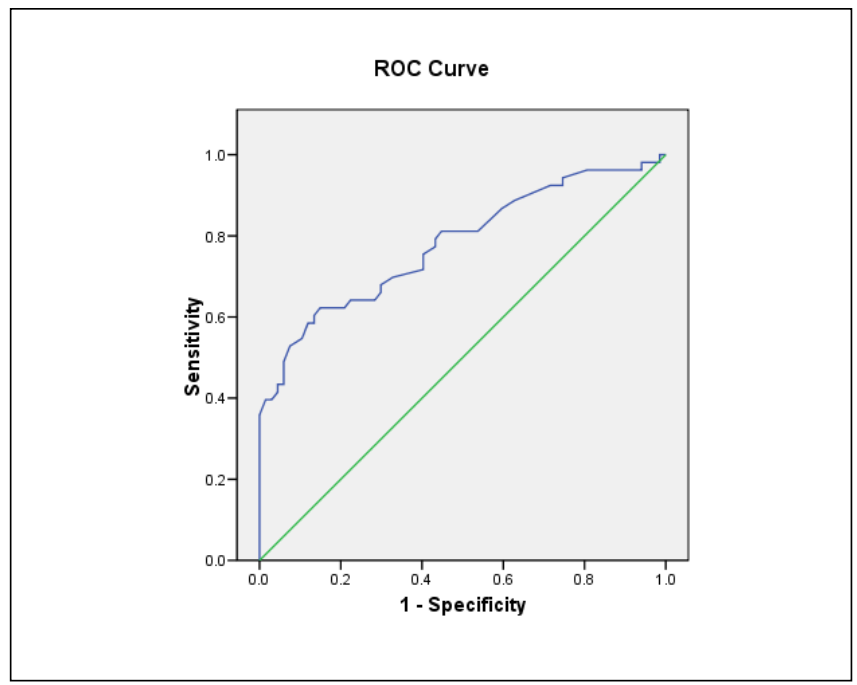

Figure 1: ROC Curve; Sensitivity and 1Specificity Graphic.

SLN: Sentinel Lymph Node,

HER-2: Human Epidermal Growth Factor

Receptor-2

Table 3: Multivariate Analysis Results

\begin{tabular}{|l|l|l|l|}
\hline & Odds Ratio & P Value & $95 \%$ Confidential \\
\hline Tumour Size $\geq 5 \mathrm{~cm}$ & 6.928 & 0.036 & $1.130-42.474$ \\
\hline Extracapsular Extension & 0.591 & 0.252 & $0.240-1.454$ \\
\hline HER-2 & 0.404 & 0.07 & $0.152-1.077$ \\
\hline LVI & 0.445 & 0.12 & $0.160-1.235$ \\
\hline Positive SLN Ratio & 3.626 & 0.005 & $1.479-8.890$ \\
\hline
\end{tabular}

LVI: Lenfovascular Invasion, SLN : Sentinel Lymph Node, HER-2 : Human Epidermal Growth Factor Receptor-2 
$(\mathrm{p}=0.93)$. In group 1 , mean tumour size was $36.21 \mathrm{~mm}( \pm 12.9)$ and it was $28.96 \mathrm{~mm}$ $( \pm 11.60)$ in group $2(\mathrm{p}=0.002)$. There was no statistically significance in KI67 status among the groups, however HER2 was significantly positive in Group1 $(\mathrm{p}=0.001)$. The mean number of metastatic SLN showed statistically significance between the groups; it was 1,83 in Group-1 and 1,29 in Group-2 ( $\mathrm{p}=0.001)$. The significant factors identified according to the univariate analysis are shown in table- 2 .

Thereafter stepwise multiple logistic regression analysis was performed for the factors those which showed significance in univariate analysis. Tumour size over $5 \mathrm{~cm}$ and the parameter positive SLN ratio (metastatic SLN/total SLN = 1) were the independent factors affecting non-SLN metastasis. The results of logistic regression analyse are shown in table-3. Group-1 presented the value 64,32 and Group-2 presented the value 45,86 according to MSKCC nomogram scoring system. It was statistically significant $(\mathrm{p}=0.001)$. The receiver operating characteristic curve (ROC) were used to describe the performance of the diagnostic value of MSKCC nomogram in non-SLN positivity (Figure-1). The area under the curve was calculated as 0.779 and showed significance $(\mathrm{p}<0.001)$.

\section{Discussion:}

Axillary lymph node metastasis is known as the most significant prognostic factor in early stage breast cancer patients. Both the treatment and survival differs according to the presence of axillary lymph node metastasis [3]. For this reason, presence and abundance of axillary lymph node metastasis is important for determining adjuvant chemotherapy depending on correct staging. Because of the complications of ALND such as seroma, lymphedema, shoulder dysfunction and arm paresthesia, surgeons targeted on limited surgery on axilla instead of complete ALND [5-7]. In accordance with the previous studies, in $40-70 \%$ of the patients SLN is the only metastatic lymph node; so there is no additional metastatic lymph node in the rest of the axilla [8-10]. As a result of these studies, determining the axillary status with non- invasive methods after diagnosing positive SLN provided matter for discussion.

In the year 2003, Van Zee et al. presented a nomogram by using retrospective analyse method throughout Memorial SloanKettering Cancer Center records. This nomogram was tested prospectively and AUC was found as 0,76 in ROC curve. Therefore, this is the first nomogram estimating the nonSLN metastasis risk [11]. In breast cancer diagnosed patients, clinicopathological characteristics such as age, ER, PR, HER2 status may vary according to race or sociaeconomic status. For example, AfricanAmerican breast cancer patients are more likely to have a triple-negative (ER-/PR/HER2-) subtype than Asian women [12]. For this reason, the validity of MSKCC nomogram is tested on patients who belong to various ethnic groups or socia-economic status by various centres and the results differ from one centre to another [13-17]. There are some other developed nomograms in literature to predict non-SLN status in patients with breast cancer with SLN metastasis as well; these include the nomogram developed by Degnim et al [Mayo nomogram], the nomogram developed by $\mathrm{Pal}$ et al [Cambridge nomogram], and the nomogram developed by Kohrt et al [Stanford nomogram] [18-20]. Nomograms may be useful tools to avoid complete axillary dissection in non-SLN negative patients. However, before being incorporated into routine clinical practice, such nomograms must be validated in independent patient populations. Among these nomograms, MSKCC nomogram is the first nomogram in literature and various validation studies have been performed to evaluate the accuracy of this nomogram in different populations, so comparable data occured in literature. For this reason, we prefered to test the validity of MSKCC nomogram in Anatolian breast cancer patients and to determine the useful parameters in estimating axillary metastasis. Anatolia is the greater part of Turkey in which people from various cultures, various ethnic groups and socio-economic status are settled. Vast of the previous studies are performed on alike people.

In breast cancer patients, non-SLN metastasis risk is due to the clinical and 
pathological characteristics of both the primary tumour and the SLN metastasis. Van Zee et al., found tumour size, LVI, the method of detection of SLNs, the number of positive and negative SLNs as the the related parameters with non-SLN metastasis; multifocality had borderline effect on non-SLN metastasis where tumour type, nuclear grade, ER status did not show significant effect on non-SLN metastasis [11].

Tumour size is also reported as a related factor with non-SLN metastasis in some other various studies [21-23]. In our study, there was significance between the nonSLN positive and negative groups according to mean tumour size $(\mathrm{p}=0.002)$ and in multivariate analysis tumour size over $5 \mathrm{~cm}$. was found as an independent factor increasing non-SLN metastasis risk $(\mathrm{p}=0.04)$. This result stated the aggravated risk corolated with tumour size. In the present study; LVI, the number of positive SLNs, extracapsular extension and the positive SLN ratio (proportion of positive SLN to total SLN) were the other factors affecting non-SLN metastasis risk in univariate analysis compatible with literature [22-24]. However, only the positive SLN ratio showed significance in multivariate analysis $(\mathrm{p}=0.005)$. In previous studies on the topic, there was no relationship between nonSLN metastasis and ER, PR and HER2 status[17,20-23]. In the present study, hormonal receptor status (ER, PR) did not affect the non-SLN metastasis risk however HER2 showed significance in univariate analysis. There are both contradicting and sustaining

\section{References:}

1. International Agency for Research on Cancer. GLOBOCAN 2012: estimated incidence, mortality and prevalence worldwide in 2012. http:// globocan. iarc. fr/Pages/fact_sheets_cancer.aspx [Accessed July 25, 2014].

2. Patani N, Martin LA, Dowsett M. Biomarkers for the clinical management of breast cancer: international perspective. Int J Cancer. 2013; 133: 1-13.

3. Chen JJ, Wu J. Management strategy of early-stage breast cancer patients with a positive sentinel lymph node with or without axillary lymph node dissection. Crit Rev Oncol Hematol. 2011; 79: 293-301. studies in literature about multifocality, nuclear grade and the number of negative SLNs $[11,17,20,23,25,26]$. In this study, mean number of negative SLNs was another factor affecting non-SLN positivity in univariate analysis but multifocality and nuclear grade were not related with non-SLN metastasis. We did not find the tumour type as a related factor with non-SLN metastasis similar to previous studies either $[11,17]$.

Van Zee et al., found AUC as 0.76 in their retrospective study and 0.77 in their prospective study [11]. In our study AUC was found as 0.78. Our results checked the validation of MSKCC nomogram. Tumor size $\geq 5 \mathrm{~cm}$ and positive SLN ratio were found to be independent factors which affect non-SLN metastasis risk in our study. The MSKCC nomogram was good discriminator of nonSLN metastasis in SLN positive Anatolian breast cancer patients. In the various validation studies of MSKCC nomogram for different nations AUC was found between $0.58-0.82$ [27]. As can be seen, this wide range of AUC is due to different breast cancer subtypes which may vary according to race or sociaeconomic status.

In a more recent study, SLNB alone resulted in similar survival compared to ALND [28], thereby there is a further increase in the importance of nomograms. We recommend that nomograms can be used in routine clinical practice after validation for the related patient population.

\section{Conflict of interest: None}

4. Cady B. Case against axillary lymphadenectomy for most patients with infiltrating breast cancer. J Surg Oncol. 1997; 66: 7-10.

5. Schrenk P, Rieger R, Shamiyeh A, Wayand W. Morbidity following sentinel lymph node biopsy versus axillary lymph node dissection for patients with breast carcinoma. Cancer. 2000; 88: 608-14.

6. Velanovich V, Szymanski W. Quality of life breast cancer patients with lymphedema. Am J Surg. 1999; 177: 184-7 
7. Krag DN. Minimal access surgery for staging regional lymph nodes: The sentinel node concept. Curr Probl Surg. 1998; 35: 951-1016.

8. Yu JC, Hsu GC, Hsieh CB, Sheu LF, Chao TY. Prediction of metastases to nonsentinel nodes by sentinel node status and primary tumor characteristics in primary breast cancer in Taiwan. World J Surg. 2005; 29: 813-8

9. Guenther JM, Hansen NM, DiFronzon LA, et al. Axillary dissection is not required for all patients with breast cancer and pozitive sentinel nodes. Arch Surg. 2003; 138: 52-6.

10. Sachdev U, Murphy K, Derzie A, Jaffer S, Bleiweiss U, Brower S. Prediction of nonsentinel Lymph node metastases in breast cancer patients. Am J Surg. 2002; 183: 213-7.

11. Van Zee KJ, Manasseh DM, Bevilacqua JL, et al. A Nomogram for Predicting the Likelihood of Additional Nodal Metastases in Breast Cancer Patients With a Positive Sentinel Node Biopsy. Ann Surg Oncol. 2003; 10: $1140-51$

12. Bauer KR, Brown M, Cress RD, Parise CA, Caggiano V. Descriptive analysis of estrogen receptor (ER)-negative, progesterone receptor (PR)negative, and HER2-negative invasive breast cancer, the so-called triple-negative phenotype: a population-based study from the California cancer Registry. Cancer. 2007; 109: 1721-8

13. Viale G, Maiorano E, Pruneri G, et al. Predicting the risk for additional axillary metastases in patients with breast carcinoma and positive sentinel lymph node biopsy. Ann Surg. 2005; 241: 319-25.

14. Alran S, De Rycke Y, Fourchotte V, et al. Validation and limitations of use of a breast cancer nomogram predicting the likelihood of non-sentinel node involvement after positive sentinel node biopsy. Ann Surg Oncol. 2007; 14: 2195-201

15. Smidt ML, Kuster DM, Van der Wilt GJ, Thunnissen FB, Van Zee KJ, Strobbe LJ. Can the Memorial SloanKettering Cancer Center nomogram predict the likelihood of nonsentinel lymph node metastases in breast cancer patients in the Netherlands. Ann Surg Oncol. 2005; 12: 1066-72.

16. Van la Parra RF, Ernst MF, Bevilacqua JL, et al. Validation of a nomogram to predict the risk of nonsentinel lymph node metastases in breast cancer patients with a positive sentinel node biopsy: Validation of the MSKCC Breast Nomogram. Ann Surg Oncol. 2009; 16: 1128-35

17. Unal B, Gur AS, Kayiran O, et al. Models for predicting non-sentinel lymph node positivity in sentinel node positive breast cancer: the importance of scoring system. Int J Clin Pract. 2008; 62: 1785-91

18. Degnim AC, Reynolds C, Pantvaidya G, et al: Nonsentinel node metastasis in breast cancer patients: Assessment of an existing and a new predictive nomogram. Am J Surg 2005; 190: 543-550.

19. Pal A, Provenzano E, Duffy SW, et al: A model for predicting non-sentinel lymph node metastatic disease when the sentinel lymph node is positive. Br J Surg 2008; 95: 302-309.

20. Kohrt HE, Olshen RA, Bermas HR, et al. New models and online calculator for predicting non-sentinel lymph node status in sentinel lymph node positive breast cancer patients. BMC Cancer. 2008; 4;8:66.

21. Chagpar AB, Scoggins CR, Martin RC , et al. Prediction of sentinel lymph node-only disease in women with invasive breast cancer; University of Louisville Breast Sentinel Lymph Node Study. Am J Surg. 2006; 192: 882-7

22. Cho J, Han W, Lee JW, et al. A scoring system to predict nonsentinel lymph node status in breast cancer patients with metastatic sentinel lymph nodes: a comparison with other scoring systems. Ann Surg Oncol. 2008; 15: 2278-86.

23. Koca B, Kuru B, Ozen N, Yoruker S, Bek Y. A breast cancer nomogram for prediction of non-sentinel node metastasis - validation of fourteen existing models. Asian Pac J Cancer Prev. 2014; 15: 1481-8.

24. A.S. Gur, B. Unal, Ozbek U, et al. Turkish Federation of BreastDisease Associations Protocol MF08-01 investigators. Validation of breast cancer nomograms for predicting the non-sentinel lymph node metastases after a positive sentinel lymph node biopsy in a multi-center study. Eur J Surg Oncol. 2010; 36: 30-5.

25. Derici S, Sevinc A, Harmancioglu O, et al. Validation of three breast cancer nomograms and a new formula for predicting non-sentinel lymph node status. Asian Pac J Cancer Prev. 2012; 13: 6181-5.

26. Kuo YL, Chen WC, Yao WJ, et al. Validation of Memorial Sloan-Kettering Cancer Center nomogram for prediction of non-sentinel lymph node metastasis in sentinel lymph node positive breast cancer patients an international comparison. Int J Surg. 2013;11:538-43.

27. Klar M, Jochmann A, Foeldi M, et al. The MSKCC nomogram for prediction the likelihood of non-sentinel node involvement in a German breast cancer population. Breast Can Res Treat 2008; 112: 523-31

28. Giuliano AE, Hunt KK, Ballman KV, et al. Axillary dissection vs no axillary dissection in women with invasive breast cancer and sentinel node metastasis: a randomized clinical trial. JAMA 2011; 9; 305: 569-75. 